\section{Government commitment to tourism and hospitality sector during COVID-19 pandemic}

Commitment to tourism and hospitality

\author{
Azizbek Allaberganov
}

School of Business and Economics, Westminster International University in

Tashkent, Tashkent, Uzbekistan

Alexander Preko

Marketing Department, University of Professional Studies,

Accra, Ghana, and

Iddrisu Mohammed

Department of Marketing and Entrepreneurship, University of Ghana, Accra, Ghana

\begin{abstract}
Purpose - The purpose of this study is to explore the tourism policy commitment of the government of Uzbekistan to bring back the tourists and sustain the tourism and hospitality sector during the Covid-19 pandemic. The study employed qualitative documentary research methodology using the thematic analysis with the support of the Nvivo 12 to analyze Google news articles published in the English language. The results demonstrated that the government of Uzbekistan employed a variety of policies and measures geared towards tourists and businesses during the pandemic. Mainly, the government showed confidence and trust in its policies by providing financial compensation to tourists if they get the Covid-19 infection, improved sanitary conditions and travel restrictions to prevent the spread of the virus. In terms of businesses, the government was dedicated to restoring and mitigating the adverse outcomes of Covid-19 in the tourism and hospitality sector by providing subsidies and certification that the company is following the sanitary protocols. The findings of this study illustrate that the government of Uzbekistan should continue feeding the media with the information related to strategies implemented towards reviving the tourism and hospitality sector, which will build the confidence of the tourists and businesses during the pandemic period.
\end{abstract}

Keywords Hospitality, Pandemic, COVID-19, Government of Uzbekistan, Tourism messages, Tourism policies

Paper type Research paper

\section{Introduction}

Since the emergence of the COVID-19 pandemic in the first quarter of 2020 , as many as $96 \%$ of the world travel destinations, consistent across the continents, have imposed some form

(C) Azizbek Allaberganov, Alexander Preko and Iddrisu Mohammed. Published in Tourism Critiques: Practice and Theory. Published by Emerald Publishing Limited. This article is published under the Creative Commons Attribution (CC BY 4.0) licence. Anyone may reproduce, distribute, translate and create derivative works of this article (for both commercial and non-commercial purposes), subject to full attribution to the original publication and authors. The full terms of this licence may be seen at http://creativecommons.org/licences/by/4.0/legalcode

The authors would like to thank the two proofreaders: Dr Theophilus Francis Gyepi-Garbrah and Veronica Adjei including the Editor and the two anonymous reviewers for their insightful and constructive comments from which the present paper greatly improved.
Received 12 February 2021 Revised 26 March 2021 Accepted 14 May 2021

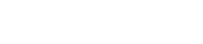


TRC

2,2

of travel restrictions to contain the spread of the virus. Some of the major restrictions that were implemented by various governments were partial or complete border shutdowns, destination-specific restrictions and self-quarantine for a number of days (UNWTO, 2020b). Because of these restrictions, many sectors of the economy in countless countries were challenged and among the highly impacted ones were the tourism and hospitality industry. According to the UNWTO's (2020a) statistics on the international travel industry, in the first 10 months of 2020, international travel decreased by 900 million travelers equaling to a loss of $\$ 935 \mathrm{bn}$ in export revenue worldwide, surpassing the losses of the world economic crisis in 2009. It is expected that the rebound of the tourism and hospitality sector will most likely occur in the second half of 2021; however, full recovery is forecasted to take up to four years.

In finding solutions to the decline in the sector, especially international arrivals, government support to businesses is paramount (Fong et al., 2020; WTTC, 2020a, 2020b), and more policy implementations are needed, such as restoring travel confidence, ensuring the safe travel and return of the international tourists back to their country of origin (OECD, 2020). Furthermore, the government's commitment to tourism policies or messages in the recovery process of the tourism and hospitality sector during COVID-19 needs to be further studied and explored (Shao et al., 2020), as it can assist the practitioners and stakeholders with the necessary information to better respond to socio-economic challenges (Wang and Ap, 2013; Yeh, 2020). There is a lack of studies on the government's role to support the tourism and hospitality sector during health-related crisis in the literature (Okuyama, 2018) from the perspective of developing regions (Shao et al., 2020; Novelli et al., 2018). Thus, the aim of this study is to examine the policies and messages of the government of Uzbekistan and strategies undertaken to bring tourists back to tourism sites. This study makes the first attempt to compile and analyze news articles on the tourism and hospitality sector during the COVID-19 pandemic from Uzbekistan to tourists at large in the world, which has been overlooked in the earlier literature. To fulfill this knowledge gap, three objectives were explored in this study:

(1) To identify the specific tourism policies that were undertaken by the government to bring back the tourists to destination sites.

(2) To explore the support provided to the businesses in the tourism and hospitality sector by the government.

(3) To understand the overall key tourism messages delivered by the government of Uzbekistan to the tourists and businesses during the COVID-19 pandemic.

The motivation for conducting this study is threefold. First, as various stakeholders in the tourism and hospitality sector are using strategies to attract the tourists back into the hospitality business (Gursoy et al., 2020), more research is called to study the significance and the effectiveness of these approaches (Gursoy and Chi, 2020). Second, Uzbekistan, as one of the many fastest-growing tourism destinations prior to the COVID-19 outbreak (WTTC, 2020a, 2020b), was also severely impacted by this pandemic. The country officially acknowledged its first cases of COVID-19 on March 15, 2020, and restrictions on public gatherings and international travel were followed (US Embassy, 2020). To restore the tourism and hospitality sector, the Uzbek Government has launched various steps that were aimed to support the struggling businesses, as well as an initiative geared toward increasing the international tourists' confidence in the country as a safe travel destination such as "Uzbekistan. Safe travel GUARANTEED" (Uzbekistan, 2021). The third perspective, the government is actively engaged in promoting tourism and hospitality during the pandemic, this is because tourism is an important and growing sector of the country's economy, comprising $2.61 \%$ of the GDP in 2018 increasing from $0.71 \%$ in 2016 (The Global Economy, 2020). Indeed, investigating the government's policies and 
approach in managing the impact of COVID-19 on the tourism and hospitality sector in Uzbekistan is imperative. The findings of this study will assist the practitioners, businesses, managers, investors, tourists and policymakers in the tourism and hospitality sector with the necessary information to understand the government's message and dedication toward the industry and guide them to formulate crucial strategies to mitigate this health crisis.

This study first presents the literature review on the tourism context of Uzbekistan, the impact of COVID-19 pandemic on tourism and hospitality sector, the response to this crisis by the government and the news articles in tourism research. Next, anchored in the standalone documentary research method (DRM), the methodology applied by this study will be discussed, followed by the analysis of the result. Finally, the study ends with the discussion and the recommendation based on the outcome of this research.

\section{Literature review}

\section{Contextual background of tourism in Uzbekistan}

Located in the heart of Central Asia, Uzbekistan has been actively pursuing the development of its tourism and hospitality sector since its inception in 1991 (Sha and Cekuta, 2018). The country possesses attractive tourism destinations such as UNESCO-listed unique and historical towns of Bukhara, Samarqand, Itchan Kala and Shakhrisabz (Airey and Shackley, 1997) as well as sport-related leisure activities and pilgrimage sites (Kantarci, 2014) to potential international and domestic tourists. International tourists all around the world are motived to visit Uzbekistan to witness these historical attractions and the adventure that the country provides (Allaberganov and Preko, 2021).

In 2016, various reforms and improvement policies were used in Uzbekistan to improve the tourism and hospitality sector further. First, to eliminate the obstacles encountered before traveling to Uzbekistan, the country abolished the old visa procedures and began introducing electronic visas (e-visas) for a single stay of 30 days (UzReport, 2018). Second, as transportation is an essential element of the travel and tourism sector, Uzbekistan has executed measures to improve its aviation industry and further travel routes were opened with additional 39 countries (Sha and Cekuta, 2018). As an outcome of these policy change reforms, the inbound tourists' volume in Uzbekistan has increased. For instance, in 2019 alone, approximately $6,748,500$ tourists visited Uzbekistan equaling to US\$1,313,032 of tourism service export, an increase from 5,346,200 visitors in 2018 (UzDaily, 2020).

Similar to other global tourism destinations, Uzbekistan was not spared from the economic consequences of COVID-19. The Uzbek Government acknowledged and confirmed its first coronavirus case on March 15, 2020 and, as of March 20, 2021, there are 81,221 COVID-19 cases and 622 deaths (Worldometers, 2021). The Uzbek policymakers launched various programs as a preventive measure to contain the spread of the virus such as restrictions of movement and border controls (US Embassy, 2020), which ultimately led to socio-economic challenges in the country. The tourism and hospitality sector suffered the most, for instance, because of travel restrictions, inbound tourist arrivals in Uzbekistan decreased by a whopping $60 \%$ compared to the same figures in 2019 (Kun.uz, 2020). On January 19, 2020, to combat the impact of COVID-19 on tourism and ensure its revival, the President of Uzbekistan Shavkat Mirziyoyev signed a decree aimed at restoring the tourism and hospitality sector in the country with strict observance of sanitation and safety protocols. To attract the tourists further, "Uzbekistan. Safe travel GUARANTEED" program was introduced by the government to ensure the tourists traveling in Uzbekistan are safe and all the sanitary and safety measures are followed (Uzbekistan, 2021). Truly, the government's role in the survival of the tourism and hospitality sector and its ultimate recovery is of utmost importance. The survival of the tourism industry will revitalize, promote destination image and brand the
Commitment to tourism and hospitality 
TRC

2,2

country among the world tourist destinations. Marketing the destination image and branding are important ingredients to the growth of the tourism industry (Lam and Ryan, 2020). To fulfill this knowledge gap, this study aims at uncovering the news articles related to the government's policy and commitment in support of its tourism and hospitality sector to have an overall understanding of the message and the strategies used by Uzbekistan.

\section{6}

\section{Tourism during COVID-19}

The international travel and tourism sector is sensitive and highly influenced by external factors such as political instability, social and economic risks and environmental disasters (Novelli et al., 2018; Preko, 2020a, 2020b), and the COVID-19 outbreak in 2020 is no different (Sigala, 2020). Initially, the negative impact of COVID-19 pandemic on the tourism and hospitality sector was largely underestimated by the policymakers and stakeholder and the magnitudes of this crisis can be unprecedented (Škare et al., 2020). As countries began to impose travel restrictions in the form of border controls and travel bans to contain the viral outbreak (UNWTO, 2020b), tourism and hospitality sector took a worldwide hit (Kreiner and Ram, 2020; Sharma et al., 2020) as the number of travelers began to decline.

In Malaysia, for instance, because of restrictions such as border controls and travel bans, many tours were canceled as a big portion of the travelers originated from China (Foo et al., 2020). With a record of 26 million tourists and ranking 15th in the world in 2018 (WorldData, 2020), Malaysia was expecting another promising tourism season in 2020. However, with the impact of COVID-19 on the global economy, Malaysia was one of the hardest-hit tourism destinations. As many as 3.5 million people could be affected in the tourism sector of Malaysia and it is predicted that $60 \%$ of the country's tourism businesses can be eliminated (Bethke, 2020). Likewise, Chinese tourism and hospitality has also suffered tremendously from the COVID-19 pandemic. Countless tours were canceled in China and Chinese tourists were banned because of border controls to enter many destinations because of fear of the virus, putting a paramount stress on international and domestic tourism in the country (Hoque et al., 2020). For instance, according to the China Tourism Academy, domestic tourism revenue is expected to decline by $52 \%$ equaling to the US $\$ 394 \mathrm{bn}$ in 2020 (Reuters, 2020). A similar case can be observed in India, another rising star in the tourism and hospitality industry. Because of the decline in international travel, overall job opportunities and regional development, as well as the country's ability to raise foreign exchange earnings, were disrupted (Jaipuria et al., 2020). Consequently, it is forecasted that India could lose up to 40 million direct and indirect jobs in the tourism and hospitality sector, which amounts to the US\$40bn (FICCI, 2020). Further impacts of COVID-19 on the tourism and hospitality sector were discussed in Nepal (Sah et al., 2020), Ukraine (Rutynskyi and Kushniruk, 2020), Bangladesh (Deb and Nafi, 2020) and Indonesia (Dinarto et al., 2020).

COVID-19 pandemic has exposed the vulnerability of the tourism and hospitality sector, having much more serious impact on the lower-income countries, and provided valuable lessons to the policymakers and stakeholders (Gössling et al., 2020). Ultimately, tourism and hospitality sector will rebound in the near future; however, the speed of recovery and to what extent the industry will resume its former glory is unknown (Baum and Hai, 2020). As studying tourism and hospitality sector during a health-related crisis is essential (Rivera, 2020), it creates the necessity to study the state response to tackle the impact of COVID-19 on the international travel and tourism sector of Uzbekistan. Findings of this study can enable a better understanding of the communication by the Government of Uzbekistan during the COVID-19 pandemic toward the tourism and hospitality sector, allowing the stakeholders, practitioners and business in this industry to formulate proper policies and strategies. 
Government policies for tourism and hospitality sector during pandemic

As the impact of COVID-19 on tourism and hospitality is paramount, stakeholders and businesses in this sector are at risk, hence making the government support during this crisis essential (OECD, 2020; Fong et al., 2020). The pandemic has reduced the international travel, causing a huge blow to many international and local economies in the world, which is ultimately affecting the global economy overall (Dupeyras et al., 2020). For instance, because of pandemic and restrictions on movement, consumer-buying behavior changed dramatically, causing a 69\% drop in purchase of non-essential items in Sub-Saharan Africa (GeoPoll, 2020). As a result, a plethora of tourism-related businesses such as hotels, restaurants and airlines witnessed lower demand by tourists (Nhamo et al., 2020). World Travel and Tourism Council strongly encourages governments to formulate policies and programs to provide necessary support for the struggling tourism and hospitality sector by protecting the livelihood of the workers involved in this industry as well as laying out financial stimulus for the companies and businesses affected by this crisis (WTTC, 2020a, 2020b).

Many governments and their agencies have used measures to restore the tourism and hospitality sector such as communication with the industry, providing subsidies and improved health-care monitoring. For instance, in China, numerous policy measures were implemented to support the tourism sector by the government that varied from region to region. Eastern China, where the population is denser compared to other parts, emphasized mainly tax reduction and financial incentives whereas tourist protection and inspection was the primary objective of central regions (Shao et al., 2020). The neighboring country of Vietnam has also proposed several relief policies to support its struggling tourism and hospitality sectors. Some of the major communications by the Vietnamese state during the pandemic were the promotion of the domestic tourism in Vietnam, followed by reevaluation of the country's visa policies as well as subsidies in the form of tax relief and financial support packages for the businesses in the tourism sphere (Quang et al., 2020).

It is evidenced that the tourism and hospitality sector is highly sensitive to global crisis such as COVID-19 (Ugur and Akbiyık, 2020) and for the survival of this industry, clear communication and support by the state become ever more crucial (Yeh, 2020). However, the survival of tourism and hospitality or its ultimate reemergence will likely vary from country to country. Some destinations might reevaluate their tourism sector and practices to become more sustainable without the immediate assistance of the state, whereas others will simply resume the regular course of business with the help of the government (Hall et al., 2020). There is a lack of studies on health crisis and tourism in the context of developing countries, creating a knowledge gap in the tourism and hospitality literature to explore the government's role in managing the tourism and hospitality sector in Uzbekistan during the pandemic. Thus, following the literature, this study attempts to explore and analyze news articles to uncover the support provided to tourism and hospitality sector by the Government of Uzbekistan during the COVID-19 pandemic.

\section{News articles in tourism research}

As a document source, news articles are cheap and easily available for the researchers (Mogalakwe, 2006) while playing an essential role in the tourism industry (Chen et al., 2020). The news coverage and articles can be detrimental in shaping the destination image while promoting the location to potential tourists. Practitioners are highly encouraged to feed the media constantly with crucial information to build the image of the location (Gabbioneta and De Carlo, 2019). A plethora of previous studies have analyzed news articles in relation to the tourism and hospitality sector and the method is becoming popular in academic literature. For instance, Phi (2020) has used news articles analysis in the study of "overtourism" media coverage. Jun and Oh (2015) studied newspaper coverage of risks and benefits associated with
Commitment to tourism and hospitality 
TRC

2,2

medical tourism being serviced in Korea using 149 articles. Dioko and Harrill (2019) analyzed English news reports between 2000 and the first half of 2017 on tourism-related fatalities and injuries to provide effective management efforts for the practitioners in the field.

News articles related to the COVID-19 pandemic and tourism were evidenced in the media as well during the recent health crisis (Şengel et al., 2020). Seraphin and Dosquet (2020) used news source coverage of pandemic impact and how it is contributing to the development of home and mountain tourism. Chen et al. (2020) performed content analysis of Chinese news during the COVID-19 pandemic investigating newspaper articles to gain a deeper understanding of news coverage during the health crisis. These authors concluded by recommending that further studies on crisis response efficiency and people's opinion during the outbreak are necessary. Thus, motivated by this, this study uses the Google News search engine to uncover published news articles in international media sources that are associated with the government approach in dealing with the tourism and hospitality recovery during and post-COVID-19 pandemic in Uzbekistan.

\section{Methodology}

This study uses a documentary qualitative method in analyzing news articles on Uzbek Government's messages and strategies to bring back the tourists to sites during the COVID-19 pandemic. DRM is a procedure where printed and online materials are systematically reviewed and analyzed (Bowen, 2009). This research method is not new and has been used in previous studies in tourism (Chen et al., 2020; Phi, 2020; Seraphin and Dosquet, 2020). Again, DRM is useful when the researcher wants to study documents that contain information regarding a phenomenon (Bailey, 1994). Being under-used in science, DRM also has its own disadvantages such as lack of detail, difficulties associated with retrieving data and selection bias. However, because of its cost-effectiveness and efficiency, the advantages of using DRM outweigh its limitations (Bowen, 2009). Following the merits that are suggested by Mogalakwe (2006), DRM is highly cost-effective and as good as other research methods such as surveys and interviews, which usually include data from organizations, libraries, newspapers and online news.

The news articles analyzed in this study were extracted from Google News from April 1, 2020 to December 31, 2020, covering nine months period (see Figure 1). To mine data, this study has used combined keywords such as "Uzbekistan," "Tourism," "Hospitality," "Covid19," "Pandemic," "Government approach," "Strategies" and "Uzbek government." The search resulted in articles about COVID-19 and tourism in Uzbekistan in the English language. Only news articles with the narrative of tourism and COVID-19 in Uzbekistan with rich content were considered and kept for this study. To ensure reliability and validity of the news articles, the united resource locators of the websites were checked and only sources from reliable media were used for analysis.

Overall, 49 newspaper articles were retrieved from the Google News search engines. Because of content and relation to the subject matter set forth in this study, only 40 news articles were useful and used for the analysis. All the news articles were compiled together in a table (Table 1) with the indicative title of the article, the source of the document and the publication date. Following the recommendation of Braun and Clarke (2006), thematic analysis was used in this study, where the articles were explored to search for common patterns by using NVivo 12 software. Authors first independently read each article thoroughly to be familiar with the texts. Next, common patterns that emerged were highlighted and coded in similar themes known as nodes. Nodes that were similar in content were grouped together and merged to develop larger themes. Next, to validate the findings, the authors compared their data and themes to reach the same conclusions. These stages allowed the researchers to validate their findings and to be consistent. In qualitative 


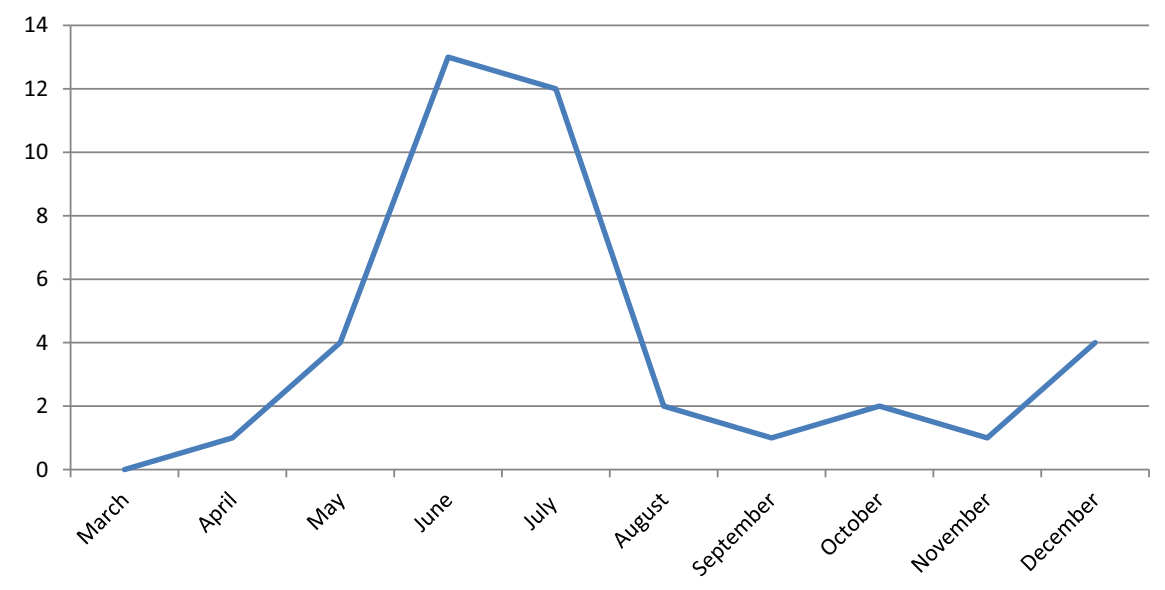

\section{Commitment to tourism and hospitality}

research, two or more researchers must reach the same conclusions after reviewing the same data (Lazaraton, 2017).

\section{Findings}

The findings of the research showed that government strategies, supports and messages for businesses and tourists were relevant to the survival of the sector within the pandemic. The study's analysis identified three major themes such as the government's support for the return of the tourists, uplifting the difficulties associated with the pandemic on the businesses and overall message of the government to the stakeholders at large.

\section{Government approach to return the tourists}

Most of the news articles examined in the study illustrated interesting highlights in regards to the government's approach in managing the tourism and hospitality sector in Uzbekistan during the pandemic. Based on the findings, the main strategies that were implemented by the Government of Uzbekistan to ensure the return of the tourists to the country were certification to businesses that they are following sanitary measures and ensuring strict adherence of sanitation protocols:

[...] Tourist sites and accommodation will also be required to gain certification from the government to ensure that they're meeting the new standards of sanitary and epidemiological safety. (Emerging Europe)

The guides, hotels, and tourist sites will have to get a certification from the local government showing they are following all the virus safety guidelines. (Times of India)

Uzbekistan, a country of 33 million that has had just a small number of Covid-related deaths, wants to assure travelers they will not be infected with the coronavirus during their stay. (The New York Times)

"We want to reassure tourists they can come to Uzbekistan," Sophie Ibbotson, Uzbekistan's tourism ambassador to the UK, said in a statement. (Vice) 


\section{TRC \\ 2,2}

\begin{tabular}{|c|c|c|}
\hline News source & Date & Headline \\
\hline 7 News & 17.07 .2020 & The country offering $\$ 3000$ if you contract coronavirus \\
\hline ABP Live & 12.11 .2020 & $\begin{array}{l}\text { Planning A Vacation? List Of Asian Countries That Are Open To } \\
\text { Foreign Travel; Check Conditions Of Stay }\end{array}$ \\
\hline 9 News & 17.07.2020 & The country offering travellers $\$ 4,000$ if they get coronavirus \\
\hline AKI Press & 30.12 .2020 & China, Uzbekistan enhance cooperation in tourism \\
\hline Big News Network & 01.10 .2020 & COVID-19: Uzbekistan Lifts Ban On International Travel \\
\hline $\mathrm{CNN}$ & 24.07.2020 & Emirates will cover medical expenses if passengers catch Covid-19 \\
\hline $\mathrm{CNN}$ & 17.07 .2020 & $\begin{array}{l}\text { From free flights to Covid-19 payouts: Can travel incentives lure visitors } \\
\text { back? }\end{array}$ \\
\hline Conde Nest Traveller & 17.12 .2020 & A Country-by-Country Guide to Asia's Travel Restrictions \\
\hline Daily Hive & 25.06 .2020 & $\begin{array}{l}\text { Uzbekistan will pay travellers } \$ 4 \mathrm{~K} \text { if they contract coronavirus while } \\
\text { visiting }\end{array}$ \\
\hline Emerging Europe & 20.07 .2020 & Uzbekistan will pay visitors 3,000 US dollars if they get Covid-19 \\
\hline Eurasianet & 28.06 .2020 & $\begin{array}{l}\text { Reports from June } 22-28 \text { on how the pandemic has upended life in } \\
\text { Central Asia and the South Caucasus }\end{array}$ \\
\hline Eurasianet & 21.06 .2020 & $\begin{array}{l}\text { Reports from June } 15-21 \text { on how the pandemic has upended life in } \\
\text { Central Asia and the South Caucasus }\end{array}$ \\
\hline Eurasianet & 07.06 .2020 & $\begin{array}{l}\text { Reports from June } 1-7 \text { on how the pandemic has upended life in Central } \\
\text { Asia and the South Caucasus }\end{array}$ \\
\hline Eurasianet & 25.05 .2020 & $\begin{array}{l}\text { Reports from May 18-24 on how the pandemic has upended life in } \\
\text { Central Asia and the South Caucasus }\end{array}$ \\
\hline Fodors Travel & 14.08.2020 & This Country Offered Tourists $\$ 3,000$ to Lure Them Back-Did It Work? \\
\hline Fox 5 & 16.07 .2020 & $\begin{array}{l}\text { From free flights to Covid-19 payouts: Can travel incentives lure visitors } \\
\text { back? }\end{array}$ \\
\hline GlobeTrender & 15.10.2020 & Six destinations that offer Covid-19 travel insurance to arrivals \\
\hline HospitalityNet & 21.12 .2020 & $\begin{array}{l}\text { WTTC Celebrates The End Of } 2020 \text { With Its 200thSafe Travels } \\
\text { Destination }\end{array}$ \\
\hline Insider & 26.06 .2020 & $\begin{array}{l}\text { All the countries offering incentives to tourists post-coronavirus, from } \\
\text { free hotel stays to spa vouchers }\end{array}$ \\
\hline Insider & 25.06 .2020 & $\begin{array}{l}\text { Uzbekistan is offering } \$ 3,000 \text { to anyone who gets the coronavirus during } \\
\text { a visit to the country }\end{array}$ \\
\hline Intellinews & 14.04 .2020 & $\begin{array}{l}\text { AFC Capital: Uzbekistan's response to COVID-19 could see economy and } \\
\text { society emerge stronger }\end{array}$ \\
\hline Lonely Planet & 24.06 .2020 & Uzbekistan is offering visitors compensation if they catch COVID-19 \\
\hline Macau Business & 08.07.2020 & Uzbekistan to re impose restrictions as coronavirus cases soar \\
\hline New Zealand Herald & 17.07.2020 & Uzbekistan to pay travellers $\$ 4500$ if they catch coronavirus \\
\hline Outlook India & 01.07 .2020 & Uzbekistan to Pay Tourists if They Contract the Coronavirus \\
\hline Reuters & 04.06 .2020 & Uzbekistan announces further easing of coronavirus restrictions \\
\hline Reuters & 30.05 .2020 & Uzbekistan extends duration of coronavirus curbs, but eases some \\
\hline Stuff & 30.06 .2020 & $\begin{array}{l}\text { Coronavirus: Uzbekistan will compensate travellers } \$ 4.6 \mathrm{k} \text { if they catch } \\
\text { Covid there }\end{array}$ \\
\hline Telegraph & 26.06 .2020 & Uzbekistan will pay tourists $\$ 3,000$ in they catch Covid-19 \\
\hline The Indian Express & 23.07.2020 & Explained: Amid Covid-19, how are countries wooing back tourists? \\
\hline The New York Times & 08.07.2020 & Visa Waivers, Vouchers, Flight Discounts and Other Travel Lures \\
\hline Timeout & 22.06 .2020 & $\begin{array}{l}\text { Uzbekistan is reopening - and will pay tourists } \$ 3,000 \text { if they catch } \\
\text { Covid-19 }\end{array}$ \\
\hline Times of India & 26.06 .2020 & $\begin{array}{l}\text { Uzbekistan's unique offer: visitors will receive } \$ 3000 \text { if they get } \\
\text { Coronavirus while visiting the country }\end{array}$ \\
\hline Travel off Path & 15.12 .2020 & Asia reopening for tourism: countries opening their borders \\
\hline Travel Weekly & 30.06 .2020 & Uzbekistan to give travellers more than $\$ 4000$ if they catch Covid-19 \\
\hline Traveller & 29.06.2020 & Uzbekistan to pay tourists who catch COVID-19 $\$ 4,370$ as compensation \\
\hline US News & 30.05 .2020 & Uzbekistan Extends Duration of Coronavirus Curbs, but Eases Some \\
\hline Vice & 20.07.2020 & Uzbekistan Will Pay You $\$ 3,000$ if You Visit and Get COVID \\
\hline Xinhua & 29.05.2020 & Uzbekistan to resume domestic, inbound tourism \\
\hline Xinhua & 18.09.2020 & Uzbekistan to resume int'l tourism next month \\
\hline
\end{tabular}

Table 1.

List of sources from Google News

Source: Authors' collections (2021) 
In addition to the increased sanitation and ensuring the trust of the travelers, Uzbek Government went even further by promising financial compensation for medical treatment for those who may end of getting the virus. This ultimately evidences that the Government of Uzbekistan was active in restoring its tourism industry as well as confident in its safety measure:

With countries currently trying to revive their tourism industries, Uzbekistan has come up with a very innovative solution that might pique the interest of travellers. Their newly-launched "Safe Travel Guaranteed" campaign provides $\$ 3,000$ to anyone who gets the coronavirus while travelling in the country. (Outlook India)

Tourists sites have reopened with a new standardized set of hygiene regulations, and the government is backing these measures with a guarantee - should you arrive and contract COVID19 , they'll offer up to $\$ 3,000$ to cover medical expenses. (Conde Nest Traveller)

Finally, the Government of Uzbekistan imposed strict border regulations and movement of the tourists. To be specific, the government divided the country into red, yellow and green zones based on the number of COVID-19 infections. Regions with the green and yellow tags were allowed to receive tourists, while red zones were off-limits. A very similar strategy was followed with international flights and tourists. Countries with fewer coronavirus cases and stable sanitary status were allowed to travel to Uzbekistan, whereas 14-day quarantine was imposed on those regions with high COVID-19 cases:

Domestic travel in Uzbekistan has been permitted since June 1 for those journeying between "no or low-infection 'green' and 'yellow' zones." International commercial flights will resume this month, with foreign visitors from "low-risk countries," including China, Japan, South Korea, and Israel, being permitted entry without any restrictions or quarantines. (Daily Hive)

Uzbekistan, which has been divided into "green", "yellow", and "red" zones depending on the rates of newly detected COVID-19 cases, has already allowed the resumption of domestic tourism and soccer games without spectators, and domestic air flights and train services have resumed. (Reuters)

\section{Government support to the businesses}

The analysis highlighted some strategies to support the businesses during the pandemic implemented by the Government of Uzbekistan such as providing financial incentives in the form of tax holidays and loans as well as certification as a proof that the business is safe to conduct operations with the tourist:

Inbound tourism will be gradually restored to countries whose citizens are allowed to enter Uzbekistan, said the ministry, adding the decree also grants tax relief and other privileges for tour operators, travel agencies and hotels till the end of year. (Xinhua)

The guides, hotels, and tourist sites will have to get a certification from the local government showing they are following all the virus safety guidelines. (Times of India)

The stability package includes broad tax breaks and holidays for the economy, with the deepest breaks (estimated at 30\%) to be given to the tourism industry; companies in the hospitality, catering and education industries being given a holiday on debt service until October 1, guaranteed by the government; UZS 500bn in loans/support made available to small and medium sized enterprises; and fast-tracking the implementation of infrastructure projects in the regions [...](Intellinews)
Commitment to tourism and hospitality 
TRC

2,2

\section{Overall message of the Government of Uzbekistan}

It was evidenced in the analysis that the Government of Uzbekistan was highly involved and dedicated to managing the impact of the COVID-19 on the tourism and hospitality sector. The findings show two key messages delivered by the government. First, the government was confident in its safety and sanitary measures being implemented in the country and was eager to win the trust of the travelers. Second, the Government of Uzbekistan was also dedicated to supporting and restoring the highly impacted tourism sector:

Uzbek President Shavkat Mirziyoyev's decree, signed on May 28, aims to take urgent measures to support the tourism industry, in an effort to mitigate the adverse impact of the pandemic, the ministry said. (Xinhua)

When Uzbekistan launched its national guarantee to visitors, the destination's tourism officials stressed they were so confident in their new safety and hygiene measures, the President was "prepared to put money where his mouth is." (7News)

[...] the "Uzbekistan: Safe Travel Guaranteed" campaign is essentially an insurance against Covid, and signals that the destination is safe to visit, while also offering a financial incentive. (Fox Five)

\section{Discussion and conclusion}

The main purpose of this study was to explore the strategic tourism policies implemented by the Government of Uzbekistan during the COVID-19 pandemic in relation to tourists and businesses in the tourism and hospitality sector at large. The findings of this study are summarized in Figure 2 where the government's main approach to tourists and businesses were dedication and confidence with the sub-themes of financial compensation, sanitary improvements, travel restrictions, stimulus package and certification. The study evidenced that Government of Uzbekistan is following the United Nations World Tourism Organization's calls for tourism and hospitality sector support such as financial and political aid for the tourism recovery and mitigating the adverse effects of the pandemic (UNWTO, 2020c).

It was discovered that the Uzbek Government was highly focused and dedicated to the revival of the tourism and hospitality sector and implemented various measures to support and restore the businesses in the country. The major discoveries from the news article sources indicated supportive measures such as stimulus packages in the forms of tax breaks and debt services and certification to ensure tourists that the local business is following the sanitary protocols. This finding is in agreement with the previous study that policies related to tax breaks and subsidies are appropriate in handling crises (Blake and Sinclair, 2003; de Sausmarez, 2004; Nhamo et al., 2020). The findings of this study hold that stimulus packages and tax breaks geared toward supporting the local business demonstrate dedication toward the tourism and hospitality sector by the Government of Uzbekistan. Possibly, this is explained by the fact that the country sees its tourism and hospitality sector as an important factor in the economic growth and the country has been actively developing the sector (Sha and Cekuta, 2018). In 2020, the contribution of tourism and hospitality to GDP in Uzbekistan was $\$ 1.6 \mathrm{bn}$ and the sector contributed $5.5 \%$ of the GDP growth (Knoema, 2021).

In terms of tourists, the Uzbek Government implemented strict border controls, increased sanitary and safety measures, as well as financial compensation as a guarantee for the procedures used in the country. This is in line with the previous findings that tourists are 


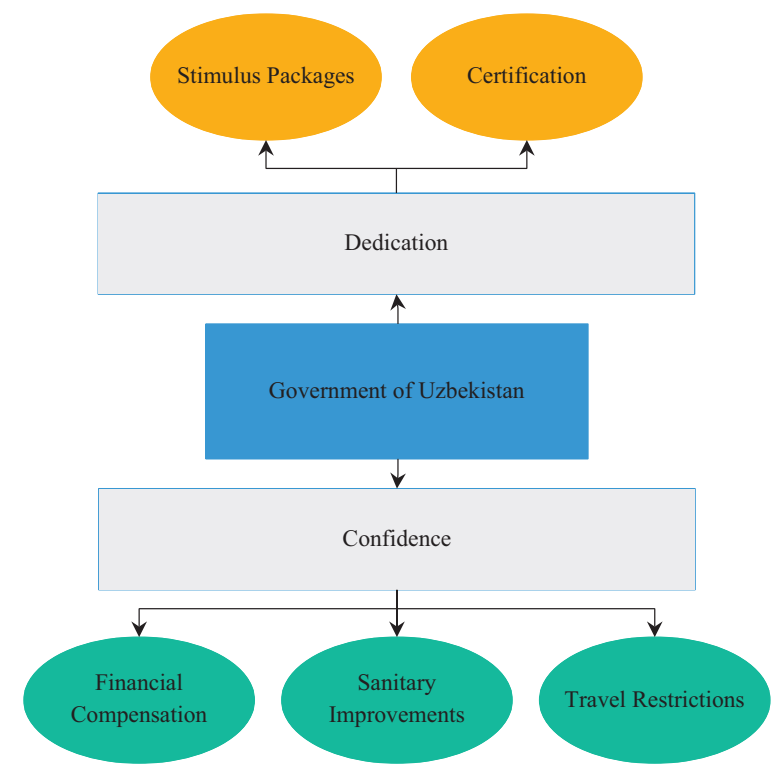

Commitment to tourism and hospitality

163

Figure 2.

Government policies, messages and strategies

affected by safety and security (Preko, 2020a, 2020b) and sanitation and hygiene of the facilities (Naumov et al., 2020). This indicates that the Government of Uzbekistan was willing and eager to increase the confidence of the tourists both domestic and international to resume their travels. Lastly, the overall message of the Government of Uzbekistan to its stakeholders was dedication to restore its tourism industry and confidence in its sanitary policies and measures. It can be evidenced that the Government of Uzbekistan was in line with guidelines recommended by the Organisation for Economic Co-operation and Development in terms of providing support to the business sector, ensuring the confidence of the travelers and supplying with clear information (OECD, 2020).

To conclude, the study of tourism sustenance and the role that the governments play during the health crisis in the context of developing nations such as Uzbekistan is limited. Thus, this study attempted to extend the literature to contribute to the knowledge gap by investigating newspaper articles publicized online concerning the support provided by the Government of Uzbekistan in revival of the tourism and hospitality sector during the COVID-19 pandemic, which goes beyond the earlier studies. For instance, China and Vietnam provided various financial relief packages and improvement of sanitations (Quang et al., 2020; Shao et al., 2020). In Uzbekistan, similar financial measures were also used to sustain the affected businesses; however, the government implemented further incentives and programs such as financial compensation to tourists to alleviate the hardships associated with the pandemic which were not found in the earlier literature. The finding of financial compensation for the tourists that might be infected by COVID-19 during the visit to Uzbekistan was one of the main contributions of this study, which differentiates this study from earlier studies (Quang et al., 2020; Shao et al., 2020) in tourism policy literature. This difference can be because of contextual issues regarding the tourism and hospitality sector in these countries. Second, the study evidenced and confirmed the commitment level of government policies in the tourism and hospitality sector (Preko, 2020a, 2020b). Specifically, the government's role in providing support to the struggling businesses in the 
TRC

2,2

tourism sector and restoring the confidence of the travelers in the safety measures used by the country were the key commitments identified in the study. Third, the study further confirmed the usefulness of online news articles in exploring the government's commitments to the tourism and hospitality sector. This is also regarded as a contribution of this study to the documentary analysis literature within a developing tourism policy perspective in the Asian continent.

Finally, it was concluded that despite the fact that the Government of Uzbekistan has taken strong stance against the COVID-19 pandemic and implemented several measures to uplift the struggling businesses and companies in the tourism and hospitality sector, some shortfalls were noticed in the media coverage in the Google News search engine. There was a lack of information related to details and the monitoring process of the policies implemented by the Government of Uzbekistan toward the businesses in the tourism and hospitality sector. For instance, types of businesses that are eligible for support and the actual number of companies registered for the government support was limited in the sources. In addition, the extent of the aid provided for these stakeholders during the pandemic was not covered in detail. Furthermore, limited information on the steps and procedures to be taken to acquire the financial support for tourists who contract the virus during the visit to Uzbekistan was also evident. Thus, providing further detailed information on the process and the effectiveness of the support measures to uplift the difficulties experienced in the tourism and hospitality sector during the COVID-19 pandemic could foster increased confidence of the tourists as well as the businesses.

\section{Implications}

The findings of this study provide insights for policy and managerial recommendations to the policymakers in the tourism and hospitality sector. First, news coverage and media play an essential role in the tourism and hospitality sector (Chen et al., 2020) and can be detrimental to destination image (Gabbioneta and De Carlo, 2019). Thus, the authors recommend continuing and further increasing the communication between the Government of Uzbekistan and the news sources and providing more information on sanitary and safety measures being implemented in the country. Next, supporting the businesses during the COVID-19 pandemic by the governments is crucial for their survival and restoration (Fong et al., 2020) and a priority must be given in providing information while limiting uncertainty (OECD, 2020). As mentioned previously, there was a lack of information related to monitoring the process and ultimate effectiveness of the government policies toward the tourism and hospitality sector. Hence, it is highly encouraged for the Government of Uzbekistan to provide additional and detailed news coverage on the various financial and non-financial support provided to the local and international businesses operating in the country as well as updated information on the monitoring process and effectiveness of these support programs. For instance, providing an online list of companies that have certified for safety and sanitation protocols can be a starting point. As for the tourists, the authors highly recommend that the Government of Uzbekistan should take measures that are more diverse in its approach in attracting the visitors back to the country. Additional measures such as providing financial aid in the form of discounts on air tickets to travelers or hotel stays can alleviate some of the financial hardships faced by many tourists after the COVID-19 pandemic.

For managerial implications, useful insights can be gained from this study to use strategic measures to mitigate the impact of COVID-19. Awareness and learning are essential in dealing with the pandemic to ensure safe travel and sustainable tourism (Gössling et al., 2020), and were poorly covered in the news articles. Thus, it is highly recommended that trainings and seminars on safety measures and sanitation protocols should be carried out to businesses and tour guides regularly by the government and 
highlighted in the media. Furthermore, businesses should pay attention to the media coverage of government policies toward the tourism and hospitality sector and develop innovative or sustainable tour packages that ensure safe and secure travel for their customers. This could also be strengthened by providing detailed media coverage or blogging on the package content and safety measures implemented. Truly, the role of the media and its content is essential in communication with the tourists and businesses, thus governments and businesses are strongly encouraged to continue and even increase feeding the newspapers with necessary information. The findings and discussion of this study provide useful insights for the stakeholders such as tourists, businesses, practitioners, policymakers, investors and managers to make key decisions and use adequate practices during the COVID-19 pandemic. Ultimately, all the implications are possible through the further successful collaboration of the key stakeholders and increased public awareness and education in the tourism and hospitality sector.

This study collected newspaper articles from the Google News search engine leading to one of the limitations in generalizing the findings. In a single study, not all the online news articles can be used; therefore, further studies are encouraged to incorporate other online news search engines such as Yahoo, LexisNexis and Microsoft Bing in a different or similar geographical context. The next limitation of this study is the utilization of newspaper articles released only in the English language. Further studies can explore news articles published in the local languages such as Uzbek and Russian to gain more insights into the government's role in the tourism and hospitality sector. Further inquiry into the national tourism and hospitality state documents can also be valuable for future studies to gain detailed explanation on the steps taken by the Government of Uzbekistan in restoring the confidence of the travelers as well as businesses. Future studies can apply either quantitative or qualitative primary data to examine the effectiveness and the successful outcome of the government policies on the tourists and businesses both pre- and postCOVID-19 pandemic as well as the response of the companies to the government's approach toward the tourism and hospitality sector. Other areas are also available for future research and should focus on the number of tourists and businesses that have benefited from government initiatives as well as the number of businesses that have been monitored and certified according to the policy. Finally, this study did not aim at investigating the reaction of the local industry to the policies, but rather advanced the understanding of the government approach to bring back tourists during the COVID-19 pandemic. Therefore, this area is also available for future research.

\section{References}

Airey, D. and Shackley, M. (1997), “Tourism development in Uzbekistan”, Tourism Management, Vol. 18 No. 4, pp. 199-208.

Allaberganov, A. and Preko, A. (2021), "Inbound international tourists' demographics and travel motives: views from Uzbekistan", Journal of Hospitality and Tourism Insights, Vol. ahead-ofprint No. ahead-of-print.

Bailey, K. (1994), Methods of Social Research, 4th ed. The Free Press, New York, NY.

Baum, T. and Hai, N.T.T. (2020), "Hospitality, tourism, human rights and the impact of COVID-19", International Journal of Contemporary Hospitality Management, Vol. 32 No. 7, pp. 2397-2407.

Bethke (2020), "The coronavirus crisis has hit tourism in Malaysia hard. [Online]", available at: www.dw.com/ en/the-coronavirus-crisis-has-hit-tourism-in-malaysia-hard/a-53392776 (accessed 18 January 2021).

Blake, A. and Sinclair, M.T. (2003), “Tourism crisis management US response to September 11”, Annals of Tourism Research, Vol. 30 No. 4, pp. 813-832.
Commitment to tourism and hospitality 
Bowen, G.A. (2009), "Document analysis as a qualitative research method", Qualitative Research Journal, Vol. 9 No. 2, pp. 27-40.

Braun, V. and Clarke, V. (2006), "Using thematic analysis in psychology", Qualitative Research in Psychology, Vol. 3 No. 2, pp. 77-101.

Chen, H., Huang, X. and Li, Z. (2020), "A content analysis of Chinese news coverage on COVID-19 and tourism", Current Issues in Tourism, pp. 1-8.

De Sausmarez, N. (2004), "Crisis management for the tourism sector: preliminary considerations in policy development", Tourism and Hospitality Planning and Development, Vol. 1 No. 2, pp. 157-172.

Deb, S.K. and Nafi, S.M. (2020), "Impact of COVID-19 pandemic on tourism: perceptions from Bangladesh", Available at SSRN, Vol. 3632798.

Dinarto, B.D., Wanto, A. and Sebastian, C.L. (2020), “COVID-19: impact on Bintan's tourism sector”, RSIS Commentaries, pp. 033-020.

Dioko, L.D.A. and Harrill, R. (2019), "Killed while traveling - trends in tourism-related mortality, injuries, and leading causes of tourist deaths from published English news reports, 2000-2017 (1H)", Tourism Management, Vol. 70, pp. 103-123.

Dupeyras, A., Haxton, P. and Stacey, J. (2020), "The covid-19 crisis and tourism: response and recovery measures to support the tourism sector in OECD countries. [Online]", available at: www.g20insights.org/policy_briefs/the-covid-19-crisis-and-tourism-response-and-recovery-measuresto-support-the-tourism-sector-in-oecd-countries/ (accessed 8 January 2021).

FICCI (2020), "Travel and tourism - survive, revive and thrive in times of COVID-19. [Online], available at", www.ficci.in/study-page.asp?spid=23252\&sectorid=40 (accessed 18 January 2021).

Fong, L.H.N., Law, R. and Ye, B.H. (2020), “Outlook of tourism recovery amid an epidemic: importance of outbreak control by the government", Annals of Tourism Research), Vol. 86.

Foo, L.-P., Chin, M.-Y., Tan, K.-L. and Phuah, K.-T. (2020), "The impact of COVID-19 on tourism industry in Malaysia", Current Issues in Tourism, Vol. 22 No. 3, pp. 1-6.

Gabbioneta and De Carlo (2019), "The role of news articles, prior destination experience, and news involvement in destination image formation", International Journal of Tourism Research, Vol. 21 No. 3, pp. 291-301.

GeoPoll (2020), "Coronavirus in Sub-Saharan Africa how Africans in 12 nations are responding to the COVID-19 outbreak. [Online]", available at: www.thecompassforsbc.org/sbcc-tools/coronavirussub-saharan-africa-how-africans-12-nations-are-responding-covid-19-outbreak $\% \mathrm{C} 2 \% \mathrm{~A} 0 \%$ C2\% A0 (accessed 19 January 2021).

Gössling, S., Scott, D. and Hall, C.M. (2020), "Pandemics, tourism and global change: a rapid assessment of COVID-19", Journal of Sustainable Tourism, Vol. 29 No. 1, pp. 1-20.

Gursoy, D. and Chi, C.G. (2020), "Effects of COVID-19 pandemic on hospitality industry: review of the current situations and a research agenda", Journal of Hospitality Marketing and Management, Vol. 29 No. 5 , pp. 527-529.

Gursoy, D., Chi, C.G. and Chi, O.H. (2020), "COVID-19 study 2 report: restaurant and hotel industry: Restaurant and hotel customers' sentiment analysis: Would they come back? If they would, WHEN?", (Report No. 2), Carson College of Business, Washington State University.

Hall, C.M., Scott, D. and Gössling, S. (2020), "Pandemics, transformations and tourism: be careful what you wish for", Tourism Geographies, Vol. 22 No. 3, pp. 577-598.

Hoque, A., Shikha, F.A., Hasanat, M.W., Arif, I. and Hamid, A.B.A. (2020), "The effect of coronavirus (COVID-19) in the tourism industry in China", Asian Journal of Multidisciplinary Studies, Vol. 3 No. 1, pp. 52-58.

Jaipuria, S., Parida, R. and Ray, P. (2020), "The impact of COVID-19 on tourism sector in India", Tourism Recreation Research, Ahead-of-Print(Ahead-of-Print), pp. 1-16. 
Jun, J. and Oh, K.M. (2015), "Framing risks and benefits of medical tourism: a content analysis of medical tourism coverage in Korean American community newspapers", Journal of Health Communication, Vol. 20 No. 6, pp. 720-727.

Kantarci (2014), "Uzbekistan, tourism”, in Jafari and Xiao (Eds), Encyclopedia of Tourism, Springer, Switzerland, Cham. pp.1-2.

Knoema (2021), “Uzbekistan. [Online]”, available at: https://knoema.com/atlas/Uzbekistan/topics/ Tourism (accessed 21 January 2021).

Kreiner, N.C. and Ram, Y. (2020), "National tourism strategies during the Covid-19 pandemic", Annals of Tourism Research,

Kun.uz (2020), "Number of tourists visiting Uzbekistan decreased by $60 \%$. [Online]", available at: https://kun.uz/en/news/2020/07/23/number-of-tourists-visiting-uzbekistan-decreased-by-60percent (accessed 20 January 2021).

Lam, I.K.V. and Ryan, C. (2020), "Can marketing create destination personality? The case of Macau", Tourism Critiques: Practice and Theory, Vol. 1 No. 1, pp. 5-20.

Lazaraton, A. (2017), Qualitative Methods of Validation, Springer, Cham.

Mogalakwe (2006), "The use of documentary research methods in social research", African Sociological Review, Vol. 10 No. 1, pp. 221-230.

Naumov, N., Varadzhakova, D. and Naydenov, A. (2020), "Sanitation and hygiene as factors for choosing a place to stay: perceptions of the Bulgarian tourists", An International Journal of Tourism and Hospitality Research, pp. 1-4.

Nhamo, G., Dube, K. and Chikodzi, D. (2020), "Tourism economic stimulus packages as a response to COVID-19", In Counting the Cost of COVID-19 on the Global Tourism Industry, Springer, Cham. pp. 353-374.

Novelli, M., Gussing Burgess, L., Jones, A., Ritchie, B.W. (2018), "No Ebola. . .still doomed” - the Ebolainduced tourism crisis", Annals of Tourism Research, Vol. 70, pp. 76-87.

OECD (2020), "Rebuilding tourism for the future: COVID-19 policy responses and recovery. [Online]", available at: www.oecd.org/coronavirus/policy-responses/rebuilding-tourism-for-the-futurecovid-19-policy-responses-and-recovery-bced9859/ (accessed 6 January 2021).

Okuyama, T. (2018), "Analysis of optimal timing of tourism demand recovery policies from natural disaster using the contingent behavior method", Tourism Management, Vol. 64 No. 1, pp. 37-54.

Phi, G.T. (2020), "Framing overtourism: a critical news media analysis", Current Issues in Tourism, Vol. 23 No. 17, pp. 2093-2097.

Preko, A. (2020a), "Tourism development: national policies and tourism priorities in Ghana", International Journal of Tourism Policy, Vol. 10 No. 4, pp. 380-391.

Preko, A. (2020b), "Safety and security concerns at the beach: views of migrant visitors in Ghana", Tourism and Hospitality Research, Vol. 21 No. 1, pp. 73-85.

Quang, T.D., Tran, T.C., Tran, V.H., Nguyen, T.T. and Nguyen, T.T. (2020), "Is Vietnam ready to welcome tourists back? Assessing COVID-19's economic impact and the Vietnamese tourism industry's response to the pandemic", Current Issues in Tourism, pp. 1-19.

Reuters (2020), “China's domestic travel revenue likely to halve to $\$ 394$ billion in 2020: report. [Online]", available at: www.reuters.com/article/us-health-coronavirus-china-tourism/chinas-domestictravel-revenue-likely-to-halve-to-394-billion-in-2020-report-idUSKBN2660Q2?il=0 (accessed 18 January 2021).

Rivera, M.A. (2020), "Hitting the reset button for hospitality research in times of crisis: Covid19 and beyond", International Journal of Hospitality Management, Vol. 87

Rutynskyi, M. and Kushniruk, H. (2020), "The impact of quarantine due to COVID-19 pandemic on the tourism industry in LVIV (Ukraine)", Problems and Perspectives in Management, Vol. 18 No. 2, p. 194. 
TRC

2,2

168

Sah, R., Sigdel, S., Ozaki, A., Kotera, Y., Bhandari, D., Regmi, P., Rabaan, A.A., Mehta, R., Adhikari, M., Roy, N. and Dhama, K. (2020), "Impact of COVID-19 on tourism in Nepal", Journal of Travel Medicine, Vol. 27 No. 6, p.taaa105.

Şengel, Ü., Çevrimkaya, M., Genç, G., Işkın, M., Zengin, B. and Sarışık, M. (2020), "An assessment on the news about the tourism industry during the COVID-19 pandemic", Journal of Hospitality and Tourism Insights, Vol. ahead-of-print No. ahead-ofprint.

Seraphin, H. and Dosquet, F. (2020), "Mountain tourism and second home tourism as post COVID-19 lockdown placebo?", Worldwide Hospitality and Tourism Themes, Vol. 12 No. 4, pp. 485-500.

Sha and Cekuta (2018), Tourism Development in Uzbekistan - Challenges and Opportunities, Caspian Policy Center, Washington, DC.

Shao, Y., Hu, Z., Luo, M., Huo, T. and Zhao, Q. (2020), "What is the policy focus for tourism recovery after the outbreak of COVID-19? A co-word analysis", Current Issues in Tourism), Vol. 24 No. 7 , pp. 1-6.

Sharma, G.D., Thomas, A. and Paul, J. (2020), "Reviving tourism industry post-COVID-19: a resiliencebased framework", Tourism Management Perspectives, Vol. 37, p. 100786.

Sigala, M. (2020), "Tourism and COVID-19: impacts and implications for advancing and resetting industry and research", Journal of Business Research, Vol. 117, pp. 312-321.

Škare, M., Soriano, D.R. and Porada-Rochoń, M. (2020), "Impact of COVID-19 on the travel and tourism industry”, Technological Forecasting and Social Change, Vol. 163, p. 120469.

The Global Economy (2020), "Uzbekistan: International tourism revenue, percent of GDP. [Online]", available at: www.theglobaleconomy.com/Uzbekistan/international_tourism_revenue_to_GDP/ (accessed 11 January 2021).

Uğur, N.G. and Akbıyık, A. (2020), "Impacts of COVID-19 on global tourism industry: a cross-regional comparison", Tourism Management Perspectives, Vol. 36, p. 100744.

UNWTO (2020a), "Impact assessment of the COVID-19 outbreak on international tourism. [Online]", available at: www.unwto.org/impact-assessment-of-the-covid-19-outbreak-on-internationaltourism (accessed 5 January 2021).

UNWTO (2020b), “COVID-19 response: $96 \%$ of global destinations impose travel restrictions, UNWTO reports. [Online]", available at: www.unwto.org/news/covid-19-response-travel-restrictions (accessed 5 January 2021).

UNWTO (2020c), “COVID-19: Putting people first. [Online]”, available at: www.unwto.org/tourismcovid-19-2020\#: :text=International $\% 20$ Tourism $\% 20$ Down $\% 2070 \% 25$,first $\% 20$ eight $\%$ 20months \% 20of\% 202020 (accessed 21 January 2021).

US Embassy (2020), “COVID-19 information. [Online]”, available at: https://uz.usembassy.gov/covid-19information/ (accessed 6 January 2021).

Uzbekistan (2021), “COVID-19 in Uzbekistan. [Online]", available at: https://uzbekistan.travel/en/o/ covid-19-in-uzbekistan/(accessed 20 January 2021).

UzDaily (2020), "About 6748500 tourists visit Uzbekistan in 2019. [Online]", available at: https:// uzdaily.uz/en/post/54048 (accessed 8 January 2021).

UzReport (2018), “Uzbekistan launches e-visa issuance system. [Online]”, available at: https://uzreport. news/society/uzbekistan-launches-e-visa-issuance-system (accessed 8 January 2021).

Wang, D. and Ap, J. (2013), "Factors affecting tourism policy implementation: a conceptual framework and a case study in China", Tourism Management, Vol. 36 No. 3, pp. 221-233.

WorldData (2020), "Tourism in Malaysia. [Online]”, available at: www.worlddata.info/asia/malaysia/ tourism.php (accessed 18 January 2021).

Worldometers (2021), "Uzbekistan. [Online]", available at: www.worldometers.info/coronavirus/ country/uzbekistan/ (accessed 20 March 2021). 
WTTC (2020a), “Government COVID-19 policies. [Online]”, available at: https://zh.wttc.org/COVID-19/ Government-Policies (accessed 7 January 2021).

WTTC (2020b), Travel and Tourism - Global Economic Impact and Trends 2020, World Travel and Tourism Council.

Commitment to tourism and hospitality

Yeh, S.-S. (2020), "Tourism recovery strategy against COVID-19 pandemic", Tourism Recreation Research, pp. 1-7.

Further reading

E-UNWTO (2019), “International tourism highlights. [Online]”, available at: www.e-unwto.org/doi/pdf/ 10.18111/9789284421152 (accessed 18 January 2021).

\section{Corresponding author}

Azizbek Allaberganov can be contacted at: aallaberganov@wiut.uz

For instructions on how to order reprints of this article, please visit our website: www.emeraldgrouppublishing.com/licensing/reprints.htm Or contact us for further details: permissions@emeraldinsight.com 